\title{
LEMBAGA WALI NANGGROE DAN MASA DEPAN PERDAMAIAN ACEH
}

\author{
M. Nazaruddin 1, Nirzalin ${ }^{2}$, Iromi Ilham ${ }^{3}$ Abdullah Akhyar Nasution 4, \\ Sjafruddin 5 \\ 1-5 Fakultas Ilmu Sosial dan Ilmu Politik Universitas Malikussaleh \\ Korespondensi : muh.nazaruddin@unimal.ac.id
}

\begin{abstract}
Abstrak: Artikel ini mengkaji tentang keberadaan Lembaga Wali Nanggroe dalam relasinya dengan masa depan perdamaian Aceh. Teknik pengumpulan data dalam studi ini adalah observasi, wawancara mendalam serta kajian dokumen yang relevan dengan topik. Hasil kajian menyatakan bahwa Wali Nanggroe adalah institusi khusus yang memang sudah berakar dalam kultur politik keacehan. Lembaga tersebut menjadi "media" penghubung dalam berbagai sistem tatanan sosial, budaya dan politik di Aceh serta memiliki otoritas dan legitimasi yang terbentuk dari basis formal maupun non-formal. Paska Helsinki, Lembaga Wali Nanggroe berperan penting dalam memproduksi stabilitas dan kohesivitas perdamaian Aceh. Posisi Lembaga Wali Nanggroe bukan saja aktor utama perdamaian, tetapi juga aktor penentu dalam merawat perdamaian Aceh. Oleh karena itu, posisinya dalam tatanan kepemerintahan Aceh harus lebih dipertegas sehingga kuat dan otonom untuk penguatan perdamaian serta penjaga kekhususan dan keistimewaan Aceh.
\end{abstract}

Kata Kunci: Wali Nanggroe, Kekhususan Aceh, Perdamaian Aceh. 


\section{A. Pendahuluan: Wali Nanggroe dan Kekhususan Aceh}

Nun jauh di sudut kota Helsinki, pada 15 Agustus 2005 silam, para penggawa dari pihak Gerakan Aceh Merdeka (GAM) dan Pemerintah Republik Indonesia (RI) melaksanakan perundingan damai yang menghasilkan nota kesepahaman. Kemudian, ia lebih akrab dengan sebutan MoU Helsinki di telinga masyarakat Aceh. Hingga saat ini, setiap tanggal tersebut masih saja diperingati sebagai momen tahunan dengan beragam seremonial sebagai rasa syukur akan perdamaian dengan harapan tak bernasib sama dengan perjanjian-perjanjian sebelumnya yang selalu berakhir sad ending. ${ }^{1}$

Sejarah panjang konflik politik Aceh dan Republik Indonesia (1953-2005) dapat dilihat dalam berbagai perspektif yang berbeda. Ada yang menganggap karena dilatarbelakangi oleh ketidakadilan pemerintah pusat, baik secara ekonomi, politik, maupun sosial budaya. Ada pula yang berpendapat persoalan ini terkait dengan isu identitas keaceehan yang semakin tergerus (Nazaruddin, 2011). Namun, satu hal yang pasti bahwa lahirnya GAM tahun 1976 tidak bisa lepas dari catatan sejarah sebelumnya yang memang memperlihatkan hubungan Aceh dan Jakarta kerap dihantam badai prahara, mulai dari masa pemberontakan DI/TII Aceh yang dipimpin oleh Daud Beureuh hingga meletusnya Gerakan Aceh Merdeka di bawah kepemimpinan Tgk. Hasan Muhammad di Tiro. Akumulasi segala bentuk kekecewaan dan ketidakadilan yang dirasa, akhirnya membawa pada perlawanan demi menunjukkan jati diri sebagai sebuah bangsa yang berdaulat. ${ }^{2}$

"Pat ujeun njang han pirang; pat prang njang han reuda"3, begitu sirat kata para tetua Aceh dulu. Ungkapan tersebut menunjukkan bahwa akan ada

\footnotetext{
${ }^{1}$ Terdapat beberapa kali upaya merajut damai antara GAM dan RI yang berakhir gagal, di antaranya pertemuan Bangkok tahun 1999, Joint Understanding on Humanitarian Pause for Aceh atau Jeda Kemanusiaan tahun 2001, dan perjanjian Tokyo di bawah bantuan Henry Dunant Center (HDC) pada tahun 2003 (Lihat: Ilham, 2015). Pun demikian dengan perjanjian yang gagal dalam sejarah Aceh paska kemerdekaan, seperti gagalnya Ikrar Lam Teeh tahun 1957 terkait upaya damai pemberontakan DI/TII (Lihat Nazaruddin, 2011).

2 Kajian asal mula konflik Aceh banyak ditelaah oleh para peneliti dan sejarawan, baik lokal, maupun internasional. Di antaranya lihat: Neta S. Pane (2001) Sejarah dan Kekuatan Aceh Merdeka; Solusi, Harapan, dan Impian. Jakarta: PT. Gramedia; Lihat juga Hasan Saleh (1992) Mengapa Aceh Bergolak? Jakarta: PT. Temprint; Lihat juga Antje Missbach (2012) Politik Jarak Jauh Diaspora Aceh. Yogyakarta: Penerbit Ombak.

${ }^{3}$ Hujan dan perang pasti akan berhenti ketika waktunya tiba (Terjemahan)
} 
kemenangan setelah penderitaan. Pun demikian dengan perang Aceh. Benar adanya, tepat pada 15 Agustus 2005, pihak GAM dan RI yang dimediasi oleh mantan Presiden Finlandia, Martti Ahtisaari akhirnya berjabat tangan. Perundingan Helsinki menjadi cara penyelesaian konflik yang menggunakan pendekatan soft power (Djumala, 2013) dan menjadi political opportunity untuk membangun tatanan baru dalam penyelenggaraan pemerintahan di Aceh. Salah satu butir kesepakatan penting yang dicapai adalah memformalkan Lembaga Wali Nanggroe dengan segala perangkat upacara dan gelarnya di bawah hukum Republik Indonesia. Supaya isi kesepahaman MoU dapat dilaksanakan dan memiliki legitimasi hukum, Pemerintah Pusat kemudian melahirkan UndangUndang No 11 tahun 2006 tentang Pemerintahan Aceh (UUPA). Produk hukum tersebut dipahami tidak sepenuhnya merupakan turunan butir-butir MoU Helsinki, termasuk di dalamnya tentang Lembaga Wali Nanggroe. ${ }^{4}$

Merujuk pada Undang-Undang Republik Indonesia Nomor 11 Tahun 2006 tentang Pemerintahan Aceh, pasal Bab XII tentang Lembaga Wali Nanggroe, Pasal 96 ayat (1) disebutkan bahwa "Lembaga Wali Nanggroe merupakan kepemimpinan adat sebagai pemersatu masyarakat yang independen, berwibawa, dan berwenang membina dan mengawasi penyelenggaraan kehidupan lembagalembaga adat, adat istiadat, dan pemberian gelar/derajat dan upacara-upacara adat lainnya". Pada ayat (2) dijelaskan bahwa Lembaga Wali Nanggroe bukan merupakan lembaga politik dan lembaga pemerintahan di Aceh. Hal ini menunjukkan bahwa kehadiran Lembaga Wali nanggroe harus bersifat independen dan otonom. Ia hadir sebagai lembaga yang memiliki marwah yang berfungsi sebagai pemersatu dan dapat mengayomi serta mendukung segala bentuk kekhususan dan kekhasan Aceh. Dengan demikian, Lembaga ini dapat diterima oleh segenap lapisan masyarakat Aceh sebagai sebuah lembaga adat yang berperan mempersatukan anak bangsa. Sebelumnya, terma Wali Nanggroe juga bisa ditemukan dalam Undang-Undang Otonomi Khusus Aceh No. 18 tahun 2001.

\footnotetext{
${ }^{4}$ Bandingkan dengan isi Undang-Undang No. 18 Tahun 2001 Tentang Otonomi Khusus bagi Provinsi Daerah Istimewa Aceh sebagai Provinsi Nanggroe Aceh Darussalam, khususnya tentang Wali Nanggroe.
} 
Menurut Rizwan55, konsep perwalian ini secara historis lahir ketika terjadi penangkapan terhadap sultan Aceh dalam peperangan melawan Belanda, sehingga secara de facto sultan tidak dapat menjalankan struktur pemerintahannya. Lalu kemudian, Wali Nanggroe hadir menggantikan sultan "sementara" untuk meneruskan fungsi pemerintahan. Sementara dalam catatan sejarah Aceh modern, sistem per-wali-an dalam makna tersebut pertama sekali diproklamirkan oleh Dr. Hasan Muhammad Di Tiro yang mengaku dirinya sebagai penerus mandat perwali-an yang diserahkan oleh Tuha Peuet Neugara (Madjeulih Neugara) kepada Teungku Chik Di Tiro Muhammad Saman, pemimpin perlawanan Aceh terhadap Belanda tahun 1885-1891. Menurut Hasan Di Tiro, sistem per-wali-an ini akan terus berpindah kepada generasi keluarga Di Tiro secara estafet. Pasalnya, perjuangan yang mengatasnamakan Aceh telah terhenti sejak syahidnya Teungku Maat DI Tiro tanggal 3 Desember 1911. Sementara pada 4 Desember 1976, perjuangan atas nama negara Aceh kembali dikibarkan oleh Hasan Tiro sehingga tanggung jawab melanjutkan perjuangan keturunan Di Tiro berada di pundaknya (Nazaruddin, 2011).

Sederetan catatan sejarah tersebut menyiratkan bahwa sistem perwalian bukan saja bagian dari sejarah politik Aceh, tetapi juga bisa dilihat sebagai bentuk reproduksi kultur politik masa lalu. Keberadaan Wali Nanggroe tidak saja hadir sebagai "ureung tuha", namun juga model kepemimpinan yang memiliki kharisma berbasis pada kultur politik yang ditaati dan diteladani.

Semangat menghadirkan lembaga Wali Naggroe di Aceh tetap harus dalam bingkai regulasi nasional. Hal ini dikarenakan UUPA secara tegas menyebutkan bahwa Aceh merupakan bagian dari Negara Kesatuan Republik Indonesia, oleh karena itu tatanan otonomi yang seluas-luasnya harus benar-benar bisa dihadirkan melalui implementasi Qanun Aceh. Otonomi yang seluas-luasnya bukan saja sekadar hak, tetapi lebih dari itu, yaitu kehadirannya merupakan kewajiban konstitusional untuk dimanfaatkan sebesar-besarnya bagi kesejahteraan di Aceh (Abdullah, 2016).

\footnotetext{
${ }^{5}$ Akademisi Universitas Malikussaleh dan mantan Aktivis Mahasiswa Aceh
} 
Mengingat pembicaraan tentang hak orang banyak dalam konteks komunal, maka melalui Qanun Aceh diharapkan hadir lembaga Wali Nanggroe yang bisa diterima oleh segenap lapisan masyarakat Aceh. Tentu saja ini harus bisa mengakomodir seluruh kepentingan masyarakat yang berada di berbagai daerah, baik itu di Pantai Utara Aceh, maupun Pantai Barat dan bagian Tengah Aceh. Sehingga Wali Nanggroe memiliki legitimasi dan otoritas yang menjadikannya sebagai sosok "ureung tuha dan tuhoe". Walaupun demikian ada fakta bahwa bagi sebagian masyarakat Aceh saat ini kehilangan imajinasi sosiologi politik terhadap institusi Wali Nanggroe karena ada praktek sejarah yang terputus disebabkan berbagai faktor.

Keberadaan Lembaga Wali Nanggroe harus menjadi culture specific sebagai penanda kekhususan Aceh. Penamaan "wali” yang berarti "penolong” atau dalam bahasa kultural masyarakat Aceh memiliki makna "orang yang bertanggung jawab akan sesuatu" selayaknya menjadi institusi yang mempersatukan masyarakat Aceh. Oleh karena itu, mengetahui eksistensi, tantangan, serta perannya dalam merawat perdamaian Aceh adalah sebuah keniscayaan.

\section{B. Metode Kajian}

Fokus utama kajian ini adalah melihat bagaimana keberadaan Lembaga Wali Nanggroe dalam upaya merawat keberlanjutan perdamaian Aceh. Oleh karena itu, tidak ada batasan geografis baku yang dijadikan lokus pengumpulan data. Dalam mengumpulkan data, penulis menggunakan metode observasi, wawancara mendalam, dan studi dokumen. Observasi dilakukan untuk mengamati dan mendengarkan bagaimana perbincangan lembaga Wali Nanggroe dalam masyarakat umum. Sementara wawancara mendalam (in-depth interview) dilakukan untuk mengetahui bagaimana keberadaan lembaga Wali Nanggroe dalam kaitannya dengan masa depan Aceh dari sudut pandang orang-orang yang memberi perhatian lebih pada keberadaan lembaga tersebut. Termasuk di dalamnya adalah tokoh adat, tokoh politik dan akademisi. Selain itu, studi dokumen juga menjadi metode yang digunakan dalam mengumpulkan data. Dalam hal ini, penulis melakukan kajian terhadap literatur-literatur yang dianggap 
relevan, baik itu dari buku, jurnal, maupun dokumen dari media elektronik. Selanjutnya, data lapangan dianalisis secara deskriptif kualitatif hingga melahirkan sebuah konklusi.

\section{Lembaga Wali Nanggroe; "Penjaga" Kekhususan dan Keistimewaan Aceh.}

Merujuk kajian teori politik modern, terdapat dua konsep penting yang saling berkaitan, yaitu politik dan pemerintahan. Teori politik fokus pada bahasan bagaimana kekuasaan diperoleh dan didistribusikan, sementara konsep pemerintahan lebih banyak membahas tentang manajemen pemerintahan, sehingga kekuasaan yang diperoleh dapat dijalankan dengan baik untuk memenuhi harapan masyarakat. Dalam kajian politik modern misalnya, struktur politik dibagi menjadi tiga elemen, yaitu: partai politik, pemilu dan parlemen. Partai politik menjadi saluran penting dalam menyampaikan aspirasi politik sehingga keberadaanya harus mampu menjadi media reproduksi pimpinanpimpinan politik. Selanjutnya, Pemilu menganalisis tentang cara bagaimana kekuasaan didapatkan. Sistem pemilu dilaksanakan dan dimodifikasi di setiap negara agar proses sirkulasi elit dalam sebuah proses politik dapat berjalan bebas dan adil. Sementara parlemen menjadi ajang kontestasi dari posisi politik yang telah didapatkan setelah pemilu berlangsung (Kurniadi, 2021).

Hal penting lainnya dari manajemen pemerintahan adalah bagaimana pola relasi antara pemerintah pusat dan pemerintah daerah dibangun dan dikomunikasikan. Bentuk negara, sistem politik yang dianut, serta sistem pemerintah yang dipakai berpengaruh dalam membentuk pola relasi tersebut. Dalam Negara kesatuan, manajemen pemerintahan pada dasarnya dikelola oleh pemerintah pusat. Namun karena berbagai faktor, misal luas wilayah dan karakter daerah yang beragam, yang menyebabkan pemerintah pusat memiliki keterbatasan untuk menangani seluruh urusan pemerintahan dalam menjamin pelayanan publik, sehingga beberapa urusan diserahkan ke pemerintahan daerah. Hal ini berbeda dengan bentuk federal dimana bagian dari negara federal pada dasarnya adalah negara-negara bagian yang menyatu menjadi satu negara. Walaupun demikian, ada juga hal-hal yang tidak bisa dilakukan oleh negara bagian, 
misalnya yang menyangkut hubungan lintas negara bagian. Dalam negara kesatuan, kewenangan yang diberikan ke daerah merupakan pemberian pemerintah pusat. Sementara dalam negara federal, urusan pemerintah federal disepakati diantara negara-negara bagian (Ferazzi, 2000).

Setelah Orde Baru, arus demokratisasi membawa perubahan yang sangat signifikan dalam melihat desentralisasi di Indonesia. Desentralisasi tidak terpisahkan dengan demokratisasi karena untuk menjadikan proses demokratisasi dapat berlangsung, harus dilakukan dengan memberikan ruang bagi timbulnya demokratisasi di daerah yang salah satunya diwujudkan dalam penghargaan keragaman lokal melalui desentralisasi. Selain itu, pemerintah juga mulai memperhatikan beberapa daerah dengan memberikan otonomi khusus (otsus), otonomi yang berbeda dari yang diberikan kepada daerah pada umumnya. Banyak orang yang menyebutkan pemberian otsus ini sebagai bentuk desentralisasi asimetris. Negara telah memberikan otonomi yang tidak seragam (asimetris) melalui pengaturan lebih lanjut mengenai kekhususan Daerah Khusus Ibukota (DKI) Jakarta, mencoba memformulasikan keistimewaan Daerah Istimewa Yogyakarta (DIY) ke dalam UU khusus, serta memberikan kekhususan melalui Undang-Undang bagi Papua dan Aceh sebagai solusi lunak atas tuntutan memisahkan diri.

Hadirnya UUPA Tahun 2006 adalah bentuk legalisasi implementasi kesepakatan MoU Helsinki dan bukti pengakuan akan kekhususan dan keistimewaan Aceh. Daya jangkau dari produk hukum tersebut semestinya lebih luas dari defenisi otonomi khusus versi Undang-Undang 18 Tahun 2001. Sejarah mencatat bahwa produk hukum UUPA Tahun 2006 seharusnya lahir memiliki kamampuan untuk memperbaiki kebijakan-kebijakan masa lalu yang memunculkan sumber ketegangan dan ketimpangan di berbagai sektor pembangunan, pelanggaran hak asasi manusia (HAM), dan pengabaian identitas lokal ke-acehan. Akan tetapi, produk UUPA tersebut disamping belum sepenuhnya seiring dan semakna dengan kesepakatan politik Helsinki, juga dalam prakteknya belum mengimplementasikan semangat otonomi yang seluas-luasnya bagi Aceh. 
Sesuai dengan MoU Helsinki, kekhususan yang dimiliki Aceh meliputi: pertama, pemberian kewenangan yang lebih luas dalam bidang perekonomian, pendidikan dan kebudayaan, kesehatan, kependudukan dan ketenagakerjaan, lingkungan hidup, dan sosial, yang dititikberatkan di tingkat provinsi. Kedua, Aceh diberi alokasi dana otsus dan dana bagi hasil Sumber Daya Alam yang persentasenya diatur dalam Undang-undang Khusus. Ketiga, Aceh diberikan keleluasaan untuk mengekspresikan identitas lokal melalui lambang daerah dan penamaan lembaga-lembaga lokal. Keempat, Aceh memiliki hak untuk membentuk partai lokal. Kelima, Aceh memiliki otoritas membentuk institusi perwakilan lain di samping Dewan Perwakilan Rakyat Daerah, yang disebut dengan Wali Nanggroe.

Lembaga Wali nanggroe sebagai salah satu identitas keacehan menjadi poin sakral untuk selalu direproduksi dan didengungkan agar tujuan kehadiran lembaga tersebut dapat tercapai. Ini juga menjadi pembuktian akan keseriusan pemerintah dalam merealisasi butir-butir MoU yang dianggap kunci terciptanya damai di bumi serambi mekkah. Tentu saja banyak dinamika yang terjadi dalam implementasi di lapangan.

Pembentukan lembaga Wali Nanggroe di Aceh adalah upaya menghadirkan entitas politik Aceh sebagai salah satu bentuk nyata kekhususan dan Keistimewaan Aceh yang dijalankan Negara. Bukan hanya itu, ia menjadi tawaran khusus dalam pendekatan penyelesaian konflik politik Aceh. Keberadaannya adalah kebutuhan. Sehingga jika terdapat perbedaan pemahaman terkait dengan hak-hak kekhususan dan keistimewaan Aceh oleh para pihak, Lembaga Wali Nanggroe dapat mengambil peran sebagai peuneutoh. Dengan demikian, pembangunan dan pelestarian perdamaian Aceh, insyaallah dapat terjaga melalui keberfungsian Lembaga Wali Nanggroe.

\section{Wali Nanggroe: Ikhtiar Merawat Damai dan Tantangan Masa Depan}

Perjuangan angkat senjata bagi GAM dalam Konflik politik yang terjadi dapat dilihat sebagai "saluran" menyampaikan aspirasi yang dihadirkan oleh pihak yang merasa dirugikan, walau kemudian pada akhirnya menemukan "saluran" lain 
yang lebih humanis; perundingan damai Helsinki. MoU Helsinki menjadi gerbang transformasi yang mengubah konstelasi sosial-politik dengan arena kontestasi yang lebih terbuka. Pun demikian dengan lembaga Wali nanggroe, Keberadaannya sangat krusial dalam perpolitikan Aceh. Ia menjadi salah satu kunci penting dalam keberhasilan penandatanganan negosiasi damai Helsinki sekaligus kunci untuk mempertahankan perdamaian. Namun semuanya akan tercapai bila kewenangan, peran, dan fungsi yang dimiliki diperjelas, diperluas, dan dipertegas melalui regulasi formal. Pada masa awal proses perdamaian Aceh, Lembaga tersebut begitu penting karena situasi politik saat itu kental terhadap preferensi GAM dan imajinasi kemerdekaan. Terlebih lagi di masa merawat perdamaian ke depan, keberadaan Wali Nanggroe jauh lebih penting dan bermakna untuk memenuhi preperensi sosio politik masyarakat Aceh yang sedang memperteguh perdamaian.

Sedikit menilik perjalanan Qanun Aceh tentang Wali Nanggroe, pembahasan rancangan Qanun Wali Nanggroe pada tahun 2007 pernah mendapat penolakan dari pihak GAM yang tergabung dalam KPA karena dianggap kewenangan yang diberikan terlalu sempit. Kala hasil pemilihan umum legislatif tahun 2009 dan mayoritas kursi parlemen dikuasai Partai Aceh, pembahasan rancangan Qanun Wali Nanggroe kembali diusulkan. Saat itu, perdebatan alot terjadi antara wakil rakyat dari partai lokal dengan wakil dari partai nasional, misalnya dalam draft Rancangan Qanun Wali Nanggroe tahun 2010, posisi Wali Nanggroe ditempatkan sebagai pemimpin politik yang hak dan kewenangannya mencakup bidang politik. Pasal 1 ayat 3 menegaskan posisi Wali Nanggroe sebagai "penguasa pemerintahan Aceh (dalam adat) yang berkedudukan lebih tinggi dalam tatanan pemerintahan Aceh, lebih tinggi dari Kepala Pemerintahan dan Parlemen Aceh dan menjadi figure pemersatu rakyat Aceh". Pada tanggal 2 november 2012, DPRA mengesahkan qanun Wali Nanggroe dalam rapat paripurna DPR Aceh sekaligus dengan menunjuk Malik Mahmud Al-Haytar sebagai Wali Nanggroe IX sebagaimana yang tercantum dalam pasal 132 Qanun Aceh Nomor 8 tahun 2012. Walaupun mendapat dukungan kuat dari Pemerintah dan parlemen Aceh, namun dalam kacamata Pemerintah Pusat yang dalam hal ini melalui Mendagri masih banyak hal yang perlu dikaji terkait peran dan wewenang yang telah dirumuskan (Ikramatoun, 2013). 
Dalam perjalanannya, penguatan dan aturan terkait lembaga Wali Nanggroe harus ditinjau kembali dalam Qanun Aceh. Oleh karena itu, pada hari Selasa, 26 Juni 2021, Panitia Khusus (Pansus) DPRA Lembaga Wali Nanggroe mengadakan pertemuan dengan Wali Nanggroe Aceh, Tgk. Malik Mahmud Al Haytar beserta jajarannya di Meuligoe Wali Nanggroe membahas penyusunan perubahan ketiga dari Qanun Aceh Nomor 8 Tahun 2012 tentang Lembaga Wali Nanggroe. Tujuan perubahan revisi Qanun adalah supaya lembaga tersebut memiliki aturan yang jelas dan terperinci terkait dengan peran, fungsi dan kewenangan. Termasuk di dalamnya terkait dengan periodesasi jabatan Wali Nanggroe, syarat calon wali nanggroe serta bendera dan lambang Wali nanggroe (aceh.tribunnews.com, 22 Juni 2021). Merujuk pada konsepsi Wali Nanggroe versi UUPA No. 11 tahun 2006, kedudukan Wali Nanggroe begitu terbatas jika dilihat dari posisi yang telah disepakati dalam MoU Helsinki. Seakan ia hanya punya peran dan wewenang dalam tatanan kepemimpinan adat. Sementara tafsir politik atas sejauh apa perannya sehingga keberadaan lembaga tersebut benar-benar menjadi satu kekhususan yang dimiliki Aceh sangat bergantung pada kekuatan politik yang dimiliki elit dan masyarakat Aceh (Nazaruddin, 2013).

Jika Qanun Aceh terkait implementasi Lembaga Wali Nanggroe ini stagnan, ada beberapa hal yang berpotensi terjadi sebagai implikasi logis dari pereduksian pemaknaan butir-butir kesepakatan damai, di antaranya: Pertama, tidak adanya tokoh panutan yang dianggap sebagai "orang tua”. Aceh saat ini masih dalam kondisi tahap-tahap perdamaian yang masih rentan (peace vulnerabilities). Para kombatan yang masih berpegang pada tali komando akan kocar-kacir di lapangan, bagai anak ayam kehilangan induk. Pada titik ini berpotensi lahirnya resistensi masyarakat yang dijewantahkan dalam berbagai bentuk, baik secara terbuka maupun tertutup. Kemunculan kelompok Din Minimi6 beberapa waktu silam yang secara terang-terangan kembali mengangkat senjata adalah bentuk nyata dari

\footnotetext{
${ }^{6}$ Din Minimi adalah kelompok sipil bersenjata di bawah kepemimpinan Nurdin bin Ismail Amat alias Din Minimi yang heboh pada 9 Oktober 2014 setelah mengadakan "jumpa pers" dengan Safaruddin, direktur Yayasan Advokasi Rakyat Aceh (YARA) dan dua wartawan -wartawan Harian Serambi Indonesia dan Metro TV- di pedalaman hutan Aceh Timur. Kelompok yang mengaku sebagai mantan kombatan GAM belum merasakan nikmatnya damai Aceh di bawah kepemimpinan Zaini Abdullah dan Muzakkir Manaf (Ilham, 2015)
} 
upaya perlawanan secara terbuka. Geliat kelompok tersebut bisa dibaca sebagai respon ketidaknyamanan dari ketidaksempurnaan implementasi MoU yang telah disepakati.

Kedua, Tidak adanya lembaga kepemimpinan yang menjadi pemersatu masyarakat dan pelestarian kehidupan masyarakat Aceh yang terintegrasi, baik secara politik, budaya maupun keagamaan. Secara kelembagaan, institusi Wali Nanggroe diharapkan bukan saja mengurus terkait adat dan budaya, namun ia harus menjadi rujukan bagi setiap isu sosial, politik, ekonomi dan agama di Aceh. Sebagaimana yang disampaikan oleh Rizwan, ${ }^{7}$

"kelembagaan wali nanggroe dalam struktur masyarakat politik pemerintahan Aceh menjadi simbol perekat dalam menjaga perdamaian. Sosok Wali Nanggroe adalah aktor dalam proses perdamain Aceh pada saat perjanjian Helsinski yang dianggap memiliki modal sosial-politik dan wibawa untuk menjaga agar mantan kombatan yang terlibat dalam konflik masa lalu bisa ikut menjaga proses perdamaian ini tetap berlangsung".

Maka dari itu, kelembagaan Wali Nanggroe sebagai wujud implementasi MoU Helsinki secara holistik, pada akhirnya harus diformalkan melalui Qanun Aceh adalah impian bersama demi merawat perdamaian Aceh di masa yang akan datang. Tata kelola pemerintahan yang baik, percepatan pembangunan masyarakat, perbaikan pendidikan, kehidupan berkeadilan, kemakmuran dan kesejahteraan merata adalah buah harapan dari pohon perdamaian. Dengan demikian, pereduksian peran lembaga wali nanggroe berpotensi melemahkan pembangunan perdamaian Aceh itu sendiri.

\section{E. Kesimpulan}

Sebagai sebuah institusi khusus yang telah berakar dalam sejarah panjang sosio-kultural politik Aceh dan kemudian disepakati dalam MoU Helsinki, Lembaga Wali Nanggroe harus menjadi payung dan penghubung dalam berbagai sistem tatanan sosial Aceh. Oleh karena itu, lembaga ini harus memiliki legitimasi struktural dan kultural yang kuat. Keberadaannya begitu penting dalam memproduksi stabilitas dan kohesivitas perdamaian Aceh. Semua itu dapat diwujudkan melalui peran dan wewenang yang diatur secara legal formal serta

\footnotetext{
${ }^{7}$ Akademisi Universitas Malikussaleh dan mantan Aktivis Mahasiswa Aceh
} 
dukungan penuh segenap masyarakat Aceh dan Pemerintah. Tidak hanya sebatas kewenangan dalam urusan adat semata, namun juga dalam hal yang lebih luas dalam tatan sosial keacehan. Redefenisi dan rekonsepsi lembaga Wali Nanggroe dalam Qanun Aceh yang ada harus dilakukan dengan mempertimbangkan kemampuan adaptasi lembaga dalam merespon persoalan yang terjadi di masyarakat hari ini maupun di masa yang akan datang.

Institusi Wali Nanggroe bukan saja aktor utama dalam perdamaian Aceh, tetapi juga aktor yang sangat menentukan dalam merawat perdamaian Aceh. Oleh karena itu, posisinya dalam tatanan kepemerintahan Aceh juga harus lebih dipertegas (kuat dan otonom) sehingga dapat lebih mengambil peran dalam penguatan perdamaian, kekhususan dan keistimewaan Aceh. Dalam konteks politik-pemerintahan, political will Lembaga eksekutif dan legislatif di Aceh menjadi faktor penting dalam menjaga kewibawaan, fungsi dan wewenang Wali Nanggroe agar sesuai dengan khittah yang sesungguhnya. Dukungan ulama serta masyarakat luas juga tidak bisa dilihat sebelah mata yang menjadi basis legitimasi sosio kultural akan keberadaan Lembaga Wali Nanggroe.

Bilamana penguatan kewenangan Lembaga Wali Nanggroe termanifestasi melalui regulasi formal, maka di saat bersamaan upaya merawat perdamaian di Aceh akan lebih luas dapat dilaksanakan. Sebab akar sejarah keberadaan Lembaga Wali Nanggroe memang hadir untuk memberi fakta bahwa pemerintahan Aceh selalu ada dalam menghimpun elemen masyarakat menuju cit-cita bersama, terutama untuk menciptakan kedamaian. Dengan kata lain, peran Wali Nanggroe sebagai kanal distributor bagi semua pihak yang ada di Aceh dalam mengakses sumberdaya yang ada untuk kesejahteraan bersama akan bisa terwujud tanpa harus bersegregasi dengan lembaga Eksekutif dan Legislatif di Aceh.

Terakhir, keberadaan Lembaga Wali Nanggroe di Aceh adalah upaya menghadirkan identitas dan entitas politik Aceh sebagai salah satu bentuk kekhususan dan Keistimewaan Aceh yang dijalankan Negara secara nyata. Ia bukan hanya tawaran khusus dalam pendekatan penyelesaian konflik politik Aceh, tetapi memang keberadaannya adalah kebutuhan. Sehingga jika terdapat perbedaan pemahaman terkait dengan hak-hak kekhususan dan keistimewaan 
Aceh oleh para pihak, Lembaga Wali Nanggroe dapat mengambil peran sebagai peuneutoh.

\section{Daftar Pustaka}

Aceh.tribunnews.com. (22 Juni 2021). DPRA Akan Revisi Qanun Lembaga Wali Nanggroe, Berikut Komentar Malik Mahmud. Diakses dari https://aceh.tribunnews.com/2021/06/22/dpra-akan-revisi-qanunlembaga-wali-nanggroe-berikut-komentar-malik-mahmud?page=all pada tanggal 03 Agustus 2021.

Abdullah, Muhammad Adli. (2016). Kedudukan Wali Nanggroe Setelah lahirnya Undang-Undang Pemerintah Aceh. Dalam "Kanun Jurnal Ilmu Hukum". Vol 18 No 2. Pp. 279-287.

Djumala, Darmansjah. (2013). Soft Power Untuk Aceh: Resolusi Konflik dan Politik Desentralisasi. Jakarta: PT Gramedia Pustaka Utama.

Ferazzi, G. (2000). "Using the "F" word: Federalism in Indonesia's Decentralization Discourse." Oxford Journals 30(2): 63-85.

Ikramatoun, Siti. (2015). Institusi Kepemimpinan Adat Aceh: Peran Wali Nanggroe dan Respon Masyarakat. Tesis: Program Pasca Sarjana Sosiologi Universitas Indonesia.

Ilham, Iromi. (2015). Aceh dalam Kuasa Awak Nanggroe: Studi Kemunculan Elit Baru dari Kalangan Mantan Pejuang GAM Pasca Penandatanganan Nota Kesepahaman MoU Helsinki. Tesis: Program Pasca Sarjana FIB Universitas Gadjah Mada.

Kurniadi, Bayu Dardias. (2012). Desentralisasi Asimetris Di Indonesia: Lembaga Administrasi Negara, Bandung.

Missbach, Antje. (2012). Politik Jarak Jauh Diaspora Aceh: Suatu Gambaran tentang Konflik Separatis di Indonesia. Yogyakarta: Penerbit Ombak.

Nazaruddin, Muhammad. (2011). Politik Identitas Perlawanan Aceh (Studi Reproduksi Identitas Keacehan Oleh Elit GAM). Disertasi : Universitas Gadjah Mada. 
Nazaruddin, Muhammad. (2013). Dialektika Wali Nanggroe: Perjuangan Dan Perdamaian Aceh. "Jurnal Sosiologi Universitas Syiah Kuala". Volume 26 3, No.3.

Nota Kesepahaman antara Pemerintah Republik Indonesia dan Gerakan Aceh Merdeka. Terjemahan resmi yang telah disetujui oleh delegasi RI dan GAM. Teks Asli tertulis dalam bahasa Inggris yang ditandatangani di Helsinki, Finlandia 15 Agustus 2005.

Pane, Neta S. (2001). Sejarah dan Kekuatan Gerakan Aceh Merdeka: Solusi, Harapan dan Impian. Jakarta: PT. Gramedia Widiasarana Indonesia.

Saleh, Hasan. (1992). Mengapa Aceh Bergolak?. Jakarta: PT. Temprint.

UNDANG UNDANG REPUBLIK INDONESIA NOMOR 11 TAHUN 2006 TENTANG PEMERINTAHAN ACEH.

UNDANG-UNDANG REPUBLIK INDONESIA NOMOR 18 TAHUN 2001 TENTANG OTONOMI KHUSUS BAGI PROVINSI DAERAH ISTIMEWA ACEH SEBAGAI PROVINSI NANGGROE ACEH DARUSSALAM. 